\title{
Could a Growth Inhibitory Factor, Present Only during Pregnancy, be Made Available to Treat Cancer in Adults? A Commentary
}

\author{
Gerald J Mizejewski* \\ Division of Translational Medicine, Wadsworth Center, New York State Department of Health, Albany, NY, USA
}

${ }^{*}$ Corresponding author: Gerald J Mizejewski, Division of Translational Medicine, Wadsworth Center, New York State Department of Health, PO Box 509, Empire State Plaza, Albany, NY, 12201-0509, USA, Tel: 518 486-5900; E-mail: gerald.mizejewski@health.ny.gov

Received: 21 Jun, 2021 | Accepted: 15 Jul, 2021 | Published: 26 Jul, 2021

Citation: Mizejewski GJ (2021) Could a Growth Inhibitory Factor, Present Only during Pregnancy, be Made Available to Treat Cancer in Adults? A Commentary. Int J Cancer Res Mol Mech 6(1): dx.doi.org/10.16966/2381-3318.149

Copyright: (C) 2021 Mizejewski GJ. This is an open-access article distributed under the terms of the Creative Commons Attribution License, which permits unrestricted use, distribution, and reproduction in any medium, provided the original author and source are credited.

\section{Abstract}

Human alpha-fetoprotein (AFP) is well-known as the "gold standard" biomarker for liver and germ cell tumors. It has also been utilized as a pregnancy screening analyte for neural tube defects as well as Down syndrome, when combined with other gestational-age dependent biomarkers. However, a lesser known and recognized property of AFP is its role in the maintenance and monitoring of fetal growth during ontogenetic development in man. Although a major function of AFP during pregnancy involves the serum transport of estrogens, fatty acids, retinoid, and other compounds, the positive and negative regulation of fetal growth is a vital additional function of AFP. Human AFP largely functions as a growth promoting agent; however, the fetal protein is able to temporarily convert to a growth inhibitory factor in stress and shock environments in the fetal milieu. The development of a transient form of AFP or its derived peptides could be harnessed for use as an adjunct therapeutic agent to treat cancer in adults.

Keywords: Disintegrin; Integrin; Peptide; Zinc; Metalloproteinase; Cancer; Clotting; Adhesion

\section{Activities of Alpha-Fetoprotein in Fetal and Adult Life}

Human alpha-fetoprotein (AFP) is a tumor-associated fetal protein, i.e., an oncofetal protein, utilized as a biomarker for both cancer and pregnancy-associated birth defects [1,2]. The oncofetal protein is produced in large quantities by the fetus in all gestational trimesters; however, it disappears except for vanishingly small amounts in the serum of normal juveniles and adults [3]. During the first year of life, serum AFP levels gradually decrease to only $8.0 \mathrm{ng} / \mathrm{ml}$ by the twelfth month. During pregnancy, AFP serves as a biologic response modifier and growth regulator, largely to promote and regulate growth of the fetus [4]. Although AFP levels in adults are barely detectable, patients with the onset of cancers such as liver and germ cell tumors produce highly elevated levels of serum AFP [5,6]. The increased serum AFP levels have been observed to enhance malignant growth, while serving as a valuable biomarker of aggressive cancer disease. It is also known that, following the synthesis and subsequent secretion of AFP in adult cancers, AFP can function as an autocrine growth stimulator $[4,5]$.

Just as AFP aids and promotes growth in the fetus, it can also enhance growth of cancer cells in adults. This was the reason that fulllength recombinant AFP was denied use in clinical trials for treating autoimmune disease in patients [7]. The use of recombinant human AFP to treat clinical patients would have been dangerous due to the findings that full-length AFP bristles with receptor binding pockets and signal transduction activation linkages that could initiate adverse cancer-associated cascade events in clinical patients (Table 1).

\section{The Presence and Activation of Transient (Intermediate) Forms of Alpha-Fetoprotein during Pregnancy}

In contrast to the above discourse, a lesser known transition form of AFP during pregnancy has been reported; this slightly denatured intermediate form of the AFP molecule has been termed "transformed AFP" (TAFP) [8]. This structurally altered form of AFP was studied in clinical patients during pregnancy and has been confirmed as a growth inhibitory version of the full-length, compactly folded AFP polypeptide $[9,10]$. Thus, TAFP has been found to represent a mildly denatured or a transitional (intermediate) form of AFP during pregnancy. Proteins that undergo such transitions are caused by a conformational change in their tertiary structure and are referred to as a "molten globular form" (MGF) of the protein. AFP was first reported to attain the MGF in the presence of low $\mathrm{pH}$ (isoelectric) conditions [11]; in addition, formation of the-MGF structure of AFP was found to be under ligand (concentration) control [11,12]. Proteins such as AFP in the MGF are a highly, flexible form which is; 1). Stored in cytoplasm; 2) undergoes rapid translocations; 3) traverses bilipid membranes; 4) engages in chaperone binding and recognition; and 5) undergoes rapid modification and degradations in lysosomes and ubiquitins. MGFs can be induced by changes in $\mathrm{pH}$, ionic strength, temperatures, oxidative and shock stresses, and excessively high ligand concentrations [11]. Recently, TAFP has been employed in clinical studies as a biomarker for third trimester adverse risks and outcomes as reported in several clinical studies [8-10]. Such 
Table 1: Alpha-fetoprotein (AFP) structure and activities.

\begin{tabular}{|c|c|c|}
\hline $\begin{array}{l}\text { Alpha-fetoprotein } \\
\text { Topic }\end{array}$ & $\begin{array}{c}\text { Biological Roles, Components, } \\
\text { Activities }\end{array}$ & References \\
\hline $\begin{array}{l}\text { 1) Alpha-fetoprotein } \\
\text { structural forms } \\
\text { variants, derivatives, } \\
\text { gene family }\end{array}$ & $\begin{array}{ll}\text { - } & \text { Carbohydrate and } \mathrm{pH} \\
\text { isoforms; } \\
\text { - } \quad 6-7 \text { immunologic epitopes } \\
\text { (antigens); } \\
\text { - } \quad \text { conformational variants } \\
\text { - } \quad \text { mRNA expressed variants } \\
\text { - } \quad \text { peptic fragments, } 3 \text { domains } \\
\text { - } \quad \text { member of albuminoid gene } \\
\text { family }\end{array}$ & {$[1-3]$} \\
\hline $\begin{array}{l}\text { 2) Alpha-fetoprotein } \\
\text { as a biomarker for } \\
\text { liver cancer }\end{array}$ & 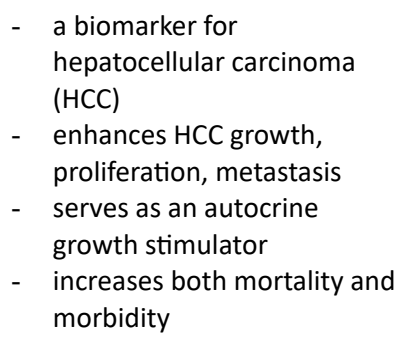 & [4-7] \\
\hline $\begin{array}{l}\text { 3) Alpha-fetoprotein } \\
\text { as a biomarker for } \\
\text { head and neck germ } \\
\text { cell tumors }\end{array}$ & $\begin{array}{l}\text { - AFP serum levels greatly } \\
\text { increase } \\
\text { - } \quad \text { Tumors located in cervical } \\
\text { areas, oral cavity, neck } \\
\text { region, eye orbits, } \\
\text { nasopharynx. } \\
\text { - } \quad \text { teratomas located in } \\
\text { mandible upper lips, scalp, } \\
\text { base of skull, gingiva }\end{array}$ & {$[1,3]$} \\
\hline
\end{tabular}

predictive adverse risk studies using TAFP have included: 1) fetal growth restriction; 2) intrauterine growth retardation; 3) fetal chronic hypoxic stress; 4) threatened pre-term labor; 5) fetal hemodynamic redistribution, and 6) fetal distress.

It is known that proteins undergo tertiary folding in the endoplasmic reticulum (ER) and are then transferred to the Golgi network prior to exocytosis into the extracellular fluids, lymphatics, and serum. However, proteins destined for circulation in the plasma/ serum must first undergo protein folding in the ER; in this process, regions of hydrophobic amino acid sequences are tucked into interior molecular folds and crevices of the protein's surface. In contrast, the hydrophilic amino acid sequences reside on the protein outer surface and extend over the exterior surface allowing for greater solubility in serum and lymphatic compartments. Thus, a conformational change of a tertiary folded protein can expose and reveal the multiple hydrophobic and/or amphipathic segments previously concealed in the protein's interior cryptic folds. One such concealed or hidden amino acid sequence stretch was discovered by the author (GJM) on the third domain of human AFP [13]. This interior motif can emerge and be exposed by a conformational change in the protein induced by high ligand concentrations in the environment surrounding the AFP molecule. Such high ligand levels are known to exist during pregnancy and have been localized to the maternal-to-placental interface [14]. The conformational change in the full-length AFP molecule in the fetal milieu is a result of exposure to high concentrations of estrogens, fatty acids, and growth factor ligands. [12,14]. Moreover, this ligand environment causes AFP to transition to a MGF that is referred to as transformed AFP (TAFP), a change which temporarily converts the normally growth promoting AFP to an inhibitory form of the protein.
Following dissipation of the stress event, AFP reverts to its normal growth promoting function.

The molecular transition of AFP to the intermediate MGF exists only until fetal homeostasis can be restored. For example, the fetus may encounter developmental events that require temporary or extended growth cessation caused by aberrant differentiation pathways, oxidative stress, or unpredicted organ/tissue overgrowth. Furthermore, fetuses might encounter unwarranted or divergent pulses of stress/shock episodes in adverse microenvironments in either the extracellular and/or intracellular compartments. Thus, growth of the fetus may require a temporary halt or pause until a more favorable fetal state of homeostasis is achieved or until compensated or compromised signal transduction pathways can be restored, and/or re-established. Such stress/shock detrimental encounters could be induced by extremes of osmolality, $\mathrm{pH}$, oxygen tension, ischemia, osmatic pressure, anemia, anoxia, and excessive high concentration ligand environments. Thus, it would seem logical that a fetal survival mechanism might be in place to aid in reducing incidents of birth defects (mistakes) during development. Such events could be avoided and aided by having a readily available and flexible fetal protein capable of temporarily converting from a growth promoting to a growth inhibitory form during periods of adverse developmental events (Table 2).

Unfortunately, AFP is only present during pregnancy and is not available to aid in the treatment of cancer in adults due to extremely low (nanogram) levels of AFP in adults. One solution to this condition would be to make available the growth inhibitory segment on fetal AFP as a cancer therapeutic agent to treat adult tumor-bearing patients. Such a treatment modality would either require: 1) the administration of full-length TAFP to adult patients which is not practical and possibly harmful, or 2) to isolate and purify the 34-mer amino acid segment on AFP which is responsible for the growth inhibition. Thus, the purified AFP-derived segment, rather than the entire 609 amino acid AFP molecule, could potentially be utilized as an anti-cancer agent in today's therapeutic cancer arsenal. To this point, multiple pre-clinical animal studies have already documented that the 34-amino acid AFP segment could pose as a viable candidate for such an endeavor as shown below.

\section{Potential Use of the AFP-Derived Growth Inhibitory Peptide as a Treatment Modality for Cancer in Adults}

The alpha-fetoprotein derived growth inhibitory segment, which is concealed on the third domain of AFP, is exposed following a

Table 2: Transformed Alpha-fetoprotein during pregnancy.

\begin{tabular}{|c|c|c|}
\hline $\begin{array}{c}\text { Alpha-fetoprotein } \\
\text { Topic }\end{array}$ & Biological Roles, Activities & References \\
\hline $\begin{array}{l}\text { 1) Alpha-fetoprotein } \\
\text { as a Transformed } \\
\text { protein (TAFP) }\end{array}$ & $\begin{array}{l}\text { - A slightly denatured form } \\
\text { - A transient form } \\
\text { - Unfolded tertiary AFP form } \\
\text { - A cryptic form of AFP }\end{array}$ & {$[8,11,13]$} \\
\hline $\begin{array}{l}\text { 2) Alpha-fetoprotein } \\
\text { as a Molten Globular } \\
\text { protein form }\end{array}$ & $\begin{array}{l}\text { - Low pH induced AFP form } \\
\text { - A ligand induced form } \\
\text { - due to Estrogens \& Fatty acid } \\
\text { - present at placental interface }\end{array}$ & {$[11-15,29]$} \\
\hline $\begin{array}{l}\text { 3) Transformed alpha- } \\
\text { fetoprotein as a fetal } \\
\text { distress biomarker }\end{array}$ & $\begin{array}{l}\text { - Risk predictor in late pregnancy } \\
\text { - fetal growth retardation } \\
\text { - fetal chronic hypoxic stress } \\
\text { - threatened preterm labor } \\
\text { - hemodynamic redistribution }\end{array}$ & {$[8-10]$} \\
\hline
\end{tabular}


conformational change in the molecule as described above. This 34-amino acid segment, termed the growth inhibitory peptide, (GIP), has been produced by peptide synthesis, purified, physiochemically characterized, subjected to multiple bio-assays, and studied in multiple cancer cell cultures [13,15-18]. In the course of testing GIP for its growth suppressive effects, GIP has been fully characterized by physiochemical methodologies. These studies revealed that GIP displayed a molecular mass of 3,573 Daltons, an isoelectric point of 4.7 , and a secondary structure exhibiting a $45 \%$ beta sheet/turns, $10 \%$ alpha helices, and $45 \%$ disordered (random) structure $[15,16]$. Computer analysis confirmed the $\beta$-sheet structure of GIP and further revealed a hairpin loop (turn) at the peptide carboxy-terminus. Further reports demonstrated that GIP exists in solution forms as dimers, trimers, and cyclized monomers [16].

The biologic activities of the 34-mer GIP involve several different functional pathways with growth inhibition as the lead property in both normal and cancer proliferation. Extensive developmental studies demonstrated that GIP functioned as a growth inhibitor and biologic response modifier in multiple non-cancer systems such as: A) rodent prepuberal uterine growth $[13,18]$; B) thyroxine - induced tail growth during frog metamorphosis; $\mathrm{C}$ ) protection against insulininduced congenital birth defects in chick embryos; D) blockage of estrogen-induced fetotoxic effects in mouse embryos; E) inhibition of hyperestrinism in pregnant mice; and F) an anti-angiogenesis factor in tumor and non-tumor growth $[19,20]$.

In comparison to the developmental growth inhibition events, the inhibition of cancer growth by GIP in animal models and in human cancer cell cultures has been well-documented $[15,17]$. It was first shown that GIP was capable of growth inhibition in both estrogendependent and estrogen-independent growth of MCF-7 human breast cancer cells in mice bearing MCF-7 xenografts in vivo, and in GI-101 tamoxifen-resistant ductal carcinomas implanted into mice $[15,16,21]$. Furthermore, GIP was shown to suppress cell-tocell contact-inhibition in MCF-7 breast cancer cells in vitro [13]. In addition, results from the National Cancer Institute (NCI) cancer therapeutic drug screening (in vitro) program showed that GIP was capable of inhibiting cancer growth in 38 of 60 different human cancer cell lines $[17,18,22]$. Such human cell lines included breast, prostate, ovarian, CNS, melanoma, kidney, lung, and colon; these were tested in a 6-day proliferation assay. GIP was also found growth suppressive in multiple different human breast cell lines which included: T-47D, BT547, MDA-MB-231 and MDA-MB-435, and in a murine mammary (sarcoma) isograft 6WI-1 [15,16,21]. Further NCI in vivo testing employing hollow fiber assays in mice, demonstrated that GIP was capable of suppressing growth by more than $50 \%$ in mice bearing breast cancer cells $[17,21]$. An amazing feature in all these animal studies was the total lack of peptide induced harmful/toxic side effects. As a cell surface membrane disrupting agent, GIP was reported to inhibit in vitro cell spreading, migration, cell-to-cell contact, cell-toextracellular matrix, and platelet aggregation [17]. Lastly, in vivo, GIP was further found to inhibit cancer cell metastasis in several mouse models [21] (Table 3).

The mechanism of action of cancer cell growth inhibition has been determined to occur in several separate steps which interfere with multiple signaling cascades and protein cross-talk interactions. Such interactive GIP activities resulted in: (1) cell cycle S-phase/G2 phase arrest; (2) prevention of cyclin inhibitor (p27, p21) degradations; (3) protection of p53 from phosphorylation inactivation; and (4) blockage of $\mathrm{K}+$ ion channels opened by growth promoting estrogens (E2) and epidermal growth factors (EGF) [22]. The events in the mechanism of action were obtained by global RNA microarray analysis, cell cycle phase determinations, and electrophysiologic measurements of cell membrane conductance and resistance. As a chemotherapeutic adjunct agent, GIP could potentially aid in alleviating the deleterious side effects of tamoxifen resistance, uterine hyperplasia/cancer, blood clotting, herceptin antibody resistance, cardiac arrhythmias, and doxorubicin's bystander cell toxicity [23]. Finally, GIP might further serve as a cancer therapeutic agent by: (1) acting as a decoy ligand for the CXCR4 chemokine receptor in cancer metastasis [24]; (2) mimicking a disintegrin by inhibiting cancer cell growth, migration, angiogenesis, and platelet aggregation [25]; (3) blocking circulating tumor cells from initiating metastatic migration [26]; (4) disabling tumor cell-to-stromal cell communication [27]; (5) inhibition of cytoskeletal factors formation required for cell migration [18]; (6) serving as a cell cycle-dependent kinase $4 / 6$ inhibitor to block G1-to-S phase cell cycle progression [28]; and (7) acting as an antimicrobial peptide for cell entry and drug delivery $[21,29]$.

\section{Summary and Concluding Remarks}

It is well-known that certain unmet needs in cancer therapies continue to exist regarding agents to block cell adherence, cell-tocell communication for cell growth and proliferation, and metastatic migratory arrest. Some of these same needs are seen to exist during fetal growth, development, and differentiation. As discussed above,

Table 3: Alpha-fetoprotein (AFP) derived peptides in cancer.

\begin{tabular}{|l|l|c|}
\hline \multicolumn{1}{|c|}{ Alpha-fetoprotein Topic } & \multicolumn{1}{|c|}{ Biological Roles, Activities } & References \\
\hline $\begin{array}{l}\text { 1) Alpha-fetoprotein-derived } \\
\text { peptides (GIP) (Growth Inhibitory } \\
\text { Peptides) functional activities }\end{array}$ & $\begin{array}{l}\text { - Development of an AFP-derived peptide termed “Growth Inhibitory Peptide" (GIP) } \\
\text { - Bioassay development, physical properties }\end{array}$ & $\begin{array}{l}\text { - studies of cell entry and uptake, } \\
\text { - participates in cross-talk and signal } \\
\text { transduction within cytoplasm }\end{array}$ \\
\hline $\begin{array}{l}\text { 2) Alpha-fetoprotein derived GIP } \\
\text { as a Biotherapeutic agent for } \\
\text { cancer }\end{array}$ & $\begin{array}{l}\text { - GIP shown to inhibit cancer growth, progression, adhesion, contact inhibition, cell } \\
\text { migration, aggregation, and metastasis } \\
\text { - interacts with cell membrane as disrupter } \\
\text { - serves as a cell membrane contact agent } \\
\text { - importance of peptide oligomeric states }\end{array}$ & [16-20] \\
\hline $\begin{array}{l}\text { 3) Alpha-fetoprotein derived GIP } \\
\text { as a chemotherapeutic agent for } \\
\text { cancer suppression }\end{array}$ & $\begin{array}{l}\text { - GIP suppresses growth of 38 of 60 cancer in vitro cell lines and in vivo mouse } \\
\text { mammary tumors } \\
\text { - reacts with cytoskeleton for cell shape changes } \\
\text { - suppresses human breast cancer growth in multiple cell culture lines }\end{array}$ & [21,23,25,26] \\
\hline
\end{tabular}


the transformed version of AFP provides the fetus with a growth promoting protein able to temporarily convert into a growth inhibiting protein entity. This conversion provides the fetus the advantage of temporarily halting or pausing further development in order to reduce and/or repair fetal malformations and multiple adverse birth events. If the serum circulating version of full length fetal AFP served only as a growth promoting/enhancing agent, then developmental mistakes would go unchecked and not be paused for repair, revision, or correction. Since the GIP motif on AFP has now been identified and purified, and because AFP serum levels are known to be greatly reduced after birth, adults lack the advantage of having a natural growth inhibitor to ward off cancer. Because the GIP segment can be synthesized in the laboratory, it could be feasible to make this growth inhibitory factor available for future development as a cancer therapeutic agent in adults. Such a factor might aid inhalting the inhibition of the growth and subsequent metastasis in patients with cancer. Even if the GIP segment could inhibit only very small cancer foci which are beginning to grow, it might find utility as a preventative agent for adult malignancy. Finally, it is imperative that only AFPderived peptides, not full length AFP, should be utilized for cancer therapy in clinical settings since the use of intact native AFP could pose a cancer risk for patients [30].

\section{Conflict of Interest}

The author declares that there are no known conflicts of interest in the preparation of this manuscript.

\section{Financial Disclosures}

None; no U.S. federal grants were used in the preparation of this paper.

\section{References}

1. Mizejewski GJ (2001) Alpha-fetoprotein structure and function: relevance to isoforms, epitopes, and conformational variants. Exp Biol Med (Maywood) 226: 377-408.

2. Mizejewski GJ (2004) Biological roles and Alpha-fetorprotein during pregnancy and perinatal development. Exp Biol Med (Maywood) 229: 439-463.

3. Mizejewski GJ (2003) Levels of Alpha-fetoprotein during pregnancy and early infancy in normal and disease states. Obstet Gynecol Surv 58: 804-826.

4. Mizejewski GJ (1997) Alpha-fetoprotein as a biologic response modifier: relevance to domain and subdomain structure. Proc Soc Exp Biol Med 215: 333-362.

5. Mizejewski GJ (2016) Does Alpha-fetoprotein Contribute to the Mortality and Morbidity of Human Heptocellular Carcinoma? A Commentary. J Hepatocell Carcinoma 3: 37-40.

6. Mizejewski GJ (2018) Alpha-fetoprotein and gastric cancer: Why is lethality more prevalent in AFP-secreting than non-secreting tumors? Canc Therapy \& Oncol Int J 9: 555753.

7. Dudich E (2007) MM-093, a recombinant human alpha-fetoprotein for the potential treatment of rheumatoid arthritis and other autoimmune diseases. Curr Opin Mol Ther 9: 603-610.

8. Gonzalez-Bugatto $F$, Foncubierta $E$, de los Angeles Bailén $M$, Illanes $S$, Hervías-Vivancos B, et al. (2009) Maternal and fetal serum transformed alpha-fetoprotein levels in normal pregnancy. J Obstet Gynecol Res 35: 271-276.

9. Bartha JL, Illanes S, Gonzalez-Bugatto F, Abdel-Fattah SA, Mizejewski GJ, et al. (2007) Maternal serum Transformed Alpha-fetoprotein levels in women with intrauterine growth retardation. Fetal Diagn Ther 22: 294-298.
10. Gonzalez-Bugatto F, de Los Angeles-Ballen R, Fernández-Macías R, Fernández-Deudero A, Hervías-Vivancos B, et al. (2009) Transformed Alpha-fetoprotein (t-AFP) Levels in Women with Threatened Preterm Labor. Gynecol Obstet Invest 68: 199-204.

11. Uversky NV, Kirkitadze MD, Narizhnera NV, Potekhin SA, AYu T (1995) Structural properties of AFP from human cord serum: The protein molecule at low $\mathrm{pH}$ possesses all the properties of the molten globule. FEBS Lett 364: 165-176.

12. Uversky VN, Narizhneva NV, Ivanova TV, Tomashevski AY (1997) Rigidity of human AFP tertiary structure is under ligand control. Biochemistry 36: 13638-13645.

13. Mizejewski GJ, Dias JA, Hauer CR, Henrikson KP, Gierthy J (1996) Alpha-fetoprotein derived synthetic peptides: assay of an estrogenmodifying regulatory segment. Mol Cell Endocrinol 118: 15-23.

14. Bennassayag C, Regoud V, Mignot TM, Hassid J, Leroy MJ, et al. (1999) Does high polyunsaturated free fatty acid level at the feta-maternal interface alter steroid hormone message during pregnancy? Prostaglandins Leukot Essent Fatty Acids 60: 393-399.

15. Mizejewski GJ, Butterstein $G$ (2006) Survey of functional activities of alpha-fetoprotein derived growth inhibitory peptides: Review and Prospects. Curr Protein Pept Sci 7: 73-100.

16. Mizejewski GJ, MacColl R (2003) Alpha-fetoprotein growth inhibitory peptides: Potential leads for cancer therapeutics. Mol Cancer Ther 2: 1243-1255.

17. Muehlemann M, Miller KD, Dauphinee M, Mizejewski GJ (2005) Review of Growth Inhibitory Peptide as a biotherapeutic agent for tumor growth, adhesion, and metastasis. Cancer Metastasis Rev 24: 441-467.

18. Mizejewski GJ, Smith G, Butterstein G (2004) Review and Proposed Action of Alpha-fetoprotein Growth Inhibitory Peptides as Estrogen and Cytoskeleton-Associated Factors. Cell Biol Int 28: 913-933.

19. Butterstein G, Mizejewski GJ (1999) Alpha-fetoprotein Inhibits Frog Metamorphosis: Implications for Protein Motif Conservation. Comp Biochem Physiol A Mol Integr Physiol 124: 39-45.

20. Butterstein G, Morrison J, Mizejewski GJ (2003) Effect of Alphafetoprotein and Derived Peptides on Insulin-and Estrogen-Induced Fetotoxicity. Fetal Diagn Ther 18: 360-369.

21. Mizejewski GJ, Mirowski M, Garnuzzek P, Marrin M, Cohen BD (2010) Targeted Delivery of Anti-Cancer Growth Inhibitory Peptides Derived from Human Alpha-fetoprotein: review of an International Multi-Center Collaborative Study. J Drug Target 18: 575-588.

22. Mizejewski GJ, Muehlemann M, Dauphinee M (2006) Update of Alpha-fetoprotein Growth Inhibitory Peptides as Biotherapeutic Agents for Tumor Growth and Metastasis. Chemotherapy 52: 83-90.

23. Mizejewski GJ (2011) Mechanism of Cancer Growth Suppression of Alpha-Fetoprotein Derived Growth Inhibitory Peptides (GIP): Comparison of GIP-34 versus GIP-8 (AFPep). Updates and Prospects. Cancers (Basel) 3: 2709-2733.

24. Mizejewski GJ (2018) Breast Cancer, Chemokines, and Metastasis: A Search for Decoy Ligands of the CXCR4 Receptor. J Neoplasms 1.

25. Mizejewski GJ (2020) Disintegrin-like Peptides Derived from Naturally-Occurring Proteins: A Proposed Adjunct Treatment for Cancer Therapy: A Commentary. Int J Cancer Res Mol Mech 5.

26. Mizejewski GJ (2018) Cancer, Circulating Tumor Cells, and Metastasis: Could Protein-Derived Peptides Fragment Impede Brain Metastosis? J Cancer Metastasis Treat 4: 27. 
27. Mizejewski GJ (2019) Breast Cancer, Metastasis and the Microenvironment: Disabling the Tumor Cell-to-Stroma Communication Network. J Cancer Metastasis Treat 5: 35-37.

28. Mizejewski GJ (2019) Breast Cancer and Cell Cycle Inhibitor (CCIs): Potential Therapeutic Strategies for $\mathrm{CCl}$ Cell Targeting and Drug Delivery. Curr Adv Oncol Res Ther 1: 1-8.

29. Vakharia D, Mizejewski GJ (2000) Human Alpha-fetoprotein Peptides Bind Estrogen Receptor and Estradiol and Suppress Breast Cancer. Breast Cancer Res Treat 63: 41-52.

30. Mizejewski GJ (2011) Therapeutic Use of Human Alpha-fetoprotein in Clinical Patients: Is a Cancer Risk Involved? Int J Cancer 128: 239242. 